\title{
BUDAPEST, BRATISLAVA AND VIENNA CONFERENCE FACILITIES, COMPARATIVE ANALYSIS
}

\author{
UDC 338.48(436:437.6:439) \\ Review \\ Endre György Bártfai \\ Received 12 May 2010 \\ Revised 14 April 2011 \\ 2 May 2011
}

\begin{abstract}
The aim of this study is to give an overview of conference facilities in three capital cities in the Central European area, along the Danube, analyse and compare their possibilities and venues. The utilized data within the study was collected from different sources, like websites of the Hungarian, Slovakian and Austrian Convention Bureaus, books dealing with convention and event management and statistics, ICCA publications. Budapest is highly ranked between cities transacting conferences for years. There are 146 different conference facilities with a total capacity for 114.000 participants. The 7 conference centres and all four- and five-star hotels suit all requirements of the different professional organizations. Budapest hosted many megaconferences; out of these the ASTA yearly session and the vein-surgery conference can be excelled. From the conference capacity of Budapest only one conference facility is missing which could host more than 5.000 participants. After analysing the conference capacities of the three Danube-band capitals - Budapest, Vienna, Bratislava, - it can be seen what kind of similarities and differences are characterizing the cities. At the end of this study the writer makes recommendations for the place of the mega-conference centre, the development of a modern and up-to-date conference database, as well as for the cooperation of the three capitals in connection with managing mega-conferences.
\end{abstract}

Keywords Conference Facilities of Budapest, Requirements of a Conference Center, Requirements of a Conference Hotel, M.I.C.E., Statistics, Cooperation

\section{INTRODUCTION}

The study belongs to the field of event tourism. At first, it is necessary to give a short overview on event tourism definitions, meanings and its importance for the development of a tourism destination.

"The demand for visitor attractions with conference and event facilities is growing. Organisers of conferences and events such as product launches, have become more competitive in choosing venues that impress delegates and guests. Organisers look for venues that will fit the theme of their event" (Whitfield, 2009). By Cooper et al (2005), the one of the main sub sectors of the tourism industry is "attractions - seen as the most important component of a holiday and including natural resources (e.g., mountains, forests and beaches), built attractions such as theme parks, fairgrounds and golf courses, and heritage sites, museums/art galleries and events." 
Tourism and Hospitality Management, Vol. 17, No. 1, pp. 131-139, 2011

E. G. Bártfai: BUDAPEST, BRATISLAVA AND VIENNA CONFERENCE FACILITIES ...

Donald Getz (2008) determined: "Planned events are spatial-temporal phenomenon, and each is unique because of interactions among the setting, people, and management systems including design elements and the program. Much of the appeal of events is that they are never the same, and you have to 'be there' to enjoy the unique experience fully; if you miss it, it's a lost opportunity."

The event tourism, as the part of the business tourism, represents non-leisure and leisure form of tourism, and event tourists are recognized, mostly, as the highestspending category of travelers (Holloway, Humphreys and Davidson, 2009).

The quality of tourism development will determine the success of the destination area. Tourism developments involve government and private developers, the first one provides the infrastructure, the second one the superstructure (Goeldner and Ritchie, 2009).

For example in Budapest the newly developed National Theater, the Millennium Park, The Palace of Arts, as well as the World Heritage designation Andrássy Avenue, the Heroes Square, which are the most important and known tourist attractions, can be used as an event facility.

"Budapest is an exciting city that is spectacular, atmospheric, entertaining, pampering and lively at the same time. You can visit it any time of the year; the city always has something new to offer to tourists because there is a rich choice of programs continuously available and this tempts you to come back" (Meszter, 2004, p.1).

Budapest - capital of Hungary - the Pearl of the Danube, is considered by its visitors to be one of the most beautiful cities in the world. Both domestic and foreign experts in conference organizing share the view that Budapest is an ideal location for conferences, meetings, incentive trips and exhibitions - the segment known as $\mathrm{MICE}^{1}-$ due to its geographical features and the facilities at its disposal.

Based on the figures provided by $\mathrm{ICCA}^{2}$, in 2005 , Budapest prestigiously ranked $8^{\text {th }}$ in the most popular conference locations in the world and it took the $20^{\text {th }}$ position in international conference and professional meeting destinations, which means a $1.8 \%$ market share (www.hcb.hu - thematic professional background material). Having improved by two positions, it ranked $6^{\text {th }}$ in 2006, with 86 events, outranking Brussels, Prague and London (www.iccaworld.com).

According to UIA $^{3}$ statistics, based on events with a minimum of 300 participants, Budapest is $12^{\text {th }}$ among the cities hosting international conferences.

For a long time only the halls in the Hungexpo area and the conference rooms of the Construction Industry Trade Union (for exclusive events) were at the organizers' disposal, therefore the capital could host only a few events. The Budapest Congress

\footnotetext{
${ }^{1}$ Meeting, Incentive, Conference, Exhibition

${ }^{2}$ International Congress and Convention Association

${ }^{3}$ Union of International Associations
} 
Tourism and Hospitality Management, Vol. 17, No. 1, pp. 131-139, 2011

E. G. Bártfai: BUDAPEST, BRATISLAVA AND VIENNA CONFERENCE FACILITIES ...

Center (Budapesti Kongresszusi Központ - BKK) was established in the framework of the Austrian-Hungarian loan contract in the middle of the 80's and this made it possible for Budapest to enter the international conference market as a strong competitor. This brought about the realization of "mega" events like the OSCE conference, the annual ASTA meeting in 1988 and the Conference on Vascular Surgery.

In this study I will try to answer the following questions:

1. What is the conference capacity of Budapest and what facilities contribute to this capacity?

2. How has Budapest ranked among conference cities recently?

3. What are the conference capacities of Budapest, Vienna and Bratislava in comparison with each other?

4. What improvements should be initiated in order to attain a better position on the market?

\section{METHOD}

In this study we relied primarily on secondary data, the sources of which were the UIA, the ICCA, the Central Statistics Office (Központi Statisztikai Hivatal - KSH), the Hungarian Congress Office (Magyar Kongresszusi Iroda - MKI) as well as Internet sources (www.hcb.hu, www.itthon.hu, www.sacka.sk, www.vienna.convention.at).

It must be noted that there are differences not only in the data gathering methods of the organizations but also in the content of their data, therefore they are difficult to compare. UIA statements report on international meetings with at least 300 participants with at least $40 \%$ foreign delegates, participants from a minimum of five countries and duration of at least three days. On the other hand the criteria identified by ICCA are as follows: minimum 50 participants at the meeting, the event is organised regularly at different locations and the delegates represent at least three nations. The Hungarian Congress Office follows the ICCA criteria and when preparing statistical analyses, considers conferences with at least 50 participants and with delegates of at least three nations present at events meeting the criteria.

It is also worth mentioning that data gathering was an easy process regarding the data from Vienna, whereas the data from Budapest and Bratislava had to be compiled after proper checking, from several sources that were sometimes contradictory. As for Budapest and Bratislava, there is no data concerning just the city; only nationwide statistics are available.

The MICE segment is made up of various meetings, incentive trips, conferences and exhibitions; these are taken into consideration for the different statistical analyses (www.iccaworld.com). 
Tourism and Hospitality Management, Vol. 17, No. 1, pp. 131-139, 2011

E. G. Bártfai: BUDAPEST, BRATISLAVA AND VIENNA CONFERENCE FACILITIES ...

\section{EXPLORING THE SITUATION}

\subsection{Requirements}

Only facilities (conference centers, conference hotels) meeting the requirements set by congress organizers $\left(\mathrm{PCO}-\mathrm{s}^{4}\right)$ have the potential to be successful in the international market.

The conference centers have to meet general requirements such as natural lighting, dimming options, electric outlets different from national regulations, a generator in case of a black-out, escalators and elevators for transporting guests, available site maps and information brochures. When it comes to security, providing emergency exits, an installed fire protection system, the guarding and protection of buildings, security points and checkpoints and separate $\mathrm{VIP}^{5}$ entrances are required. The building must have a large and bright entrance hall where one can easily look around and where the participants are assisted by an information desk, a news center and signs; from here they can approach the other halls, the locations of which are shown on maps. When planning the interiors and the sizes of the meeting rooms, one should consider the needs, the objectives set and the expectations of the segment of the market that is targeted. As for meeting rooms, it is expedient to build a large hall (plenary hall), a large panel room, two smaller panel rooms, as well as a poster-panel room and additional smaller rooms. Apart from the conference rooms, the construction of study rooms and offices, exhibition areas, press rooms, video conference facilities, catering facilities, a coatroom and toilets are also required. It is important that the conference center be easy to approach by public transport, car or bus. One also has to ensure the handicapped-accessibility of the whole center. Preferably, there should be a bank counter, a post counter, a central photocopying unit, an effective call center, phone booths suitable for international calls, closed-circuit television and an electronic message center as well as an adequate security system (www.hcb.hu).

In case the conference is organized in a hotel, there are quite a few requirements set by conference organizers for a conference hotel, as well. The capacity of the conference rooms of the hotel should be appropriate, the construction of a large hall and several smaller rooms are required, proper ventilation, heating and air conditioning need to be provided. There should be natural lighting and a means of dimming the rooms. Basic stage technology, audio-visual devices and equipment and an experienced technical staff need to be provided as well as offices close to the rooms. The conference manager is one of the members of the management; who maintains contact between the organisers of the conference and the management of the hotel, informs hotel staff about the details of the conference and the organisers' requirements and coordinates the conference-related activities of the various units of the hotel. Catering means the hotel is responsible for meals and coffee breaks and makes sure the meals are always served on time. Accessibility is important in the case of hotels as well, along with a separate coatroom, a registration desk with a computer, parking facilities for cars and buses, orientation signs for participants and ensuring the handicapped-accessibility of the

\footnotetext{
${ }^{4}$ Professional Congress Organizer

${ }^{5}$ Very Important Person
} 
Tourism and Hospitality Management, Vol. 17, No. 1, pp. 131-139, 2011

E. G. Bártfai: BUDAPEST, BRATISLAVA AND VIENNA CONFERENCE FACILITIES ...

building. The people organizing and managing the conference should have offices and telephone lines at their disposal with their own telephone numbers, if possible. Other services include continuous attention given to the cleanliness of the event halls and rooms, keeping the coatrooms open, door tending duty, first aid room in the hotel, closed-circuit televisions and an electronic message center (www.hcb.hu).

\subsection{Budapest's Conference Capacity}

At present, Budapest could host more than 114,000 conference guests at the same time, at altogether 146 locations. By conference locations, we mean hotels and other facilities (museums, palaces, special locations, conference centers). There are a total of 92 three-star, four-star and five-star hotels, providing 396 meeting/conference rooms for the MICE segment. In accordance with international standards, museums, palaces, special locations and conference centers count as other conference locations. At the moment, one can find 54 such locations in Budapest with a total of 250 rooms.

Table 1: The conference capacity of Budapest on June 30, 2007

\begin{tabular}{|l|c|c|c|c|c|}
\hline & Number & $\begin{array}{c}\text { Number } \\
\text { of Rooms }\end{array}$ & Average & $\begin{array}{c}\text { Minimum } \\
\text { Capacity* }\end{array}$ & $\begin{array}{c}\text { Maximum } \\
\text { Capacity* }\end{array}$ \\
\hline $5^{*}$ & 13 & 96 & 7.4 & 4,614 & 12,534 \\
\hline $4^{*}$ & 34 & 170 & 5.0 & 5,570 & 13,008 \\
\hline $3^{*}$ & 45 & 130 & 2.9 & 6,271 & 10,400 \\
\hline I. $\boldsymbol{\Sigma}$ & $\mathbf{9 2}$ & $\mathbf{3 9 6}$ & $\mathbf{4 . 3}$ & $\mathbf{1 6 , 4 5 5}$ & $\mathbf{3 5 , 9 4 2}$ \\
\hline Museums & 4 & 15 & 3.7 & 2,840 & 4,120 \\
\hline Palaces & 12 & 61 & 5.0 & 5,357 & 8,180 \\
\hline $\begin{array}{l}\text { Special } \\
\text { Locations }\end{array}$ & 31 & 104 & 3.3 & 28,996 & 44,651 \\
\hline $\begin{array}{l}\text { Conference } \\
\text { Center }\end{array}$ & 7 & 70 & 10.0 & 9,163 & 21,449 \\
\hline II. $\boldsymbol{\Sigma}$ & $\mathbf{5 4}$ & $\mathbf{2 5 0}$ & $\mathbf{4 . 6}$ & $\mathbf{4 6 , 3 5 6}$ & $\mathbf{7 8 , 4 0 0}$ \\
\hline $\boldsymbol{\Sigma}$ (I.-II.) & $\mathbf{1 4 6}$ & $\mathbf{6 4 6}$ & $\mathbf{4 . 4}$ & $\mathbf{6 2 , 8 1 1}$ & $\mathbf{1 1 4 , 3 4 2}$ \\
\hline
\end{tabular}

*The minimum capacity means the smallest number of guests that can be accommodated in the room at the same time, while the maximum number capacity means the largest number of guests, depending on the setting of the room (a meeting-type setting means the smallest number of guests, a standing reception means the largest number of guests).

Edited by: Bártfai 2007

Source: www.itthon.hu,www.hcb.hu

As seen in Table 1, a third of the hotel conference room capacity in Budapest can be found in the three-star category and most of them do not meet the requirements set by the PCO-s for conference hotels therefore, are only suitable for meetings with a smaller number of participants or continuing education courses. Almost all five-star hotels satisfy the requirements and in this case, the technical conditions also fulfill requirements at a high standard. Four-star hotels also correspond to the norms described in the IAPCO ${ }^{6}$ statement; however, in many cases can only host events with fewer participants.

${ }^{6}$ International Association of Professional Congress Organizers 
Tourism and Hospitality Management, Vol. 17, No. 1, pp. 131-139, 2011

E. G. Bártfai: BUDAPEST, BRATISLAVA AND VIENNA CONFERENCE FACILITIES ...

Diagram 1: The conference capacity of hotels in Budapest

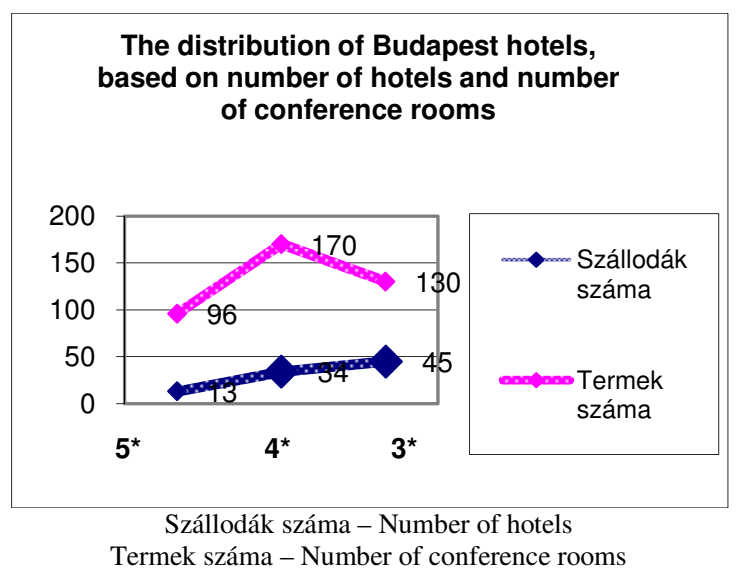

Diagram 2: Other conference capacities in Budapest

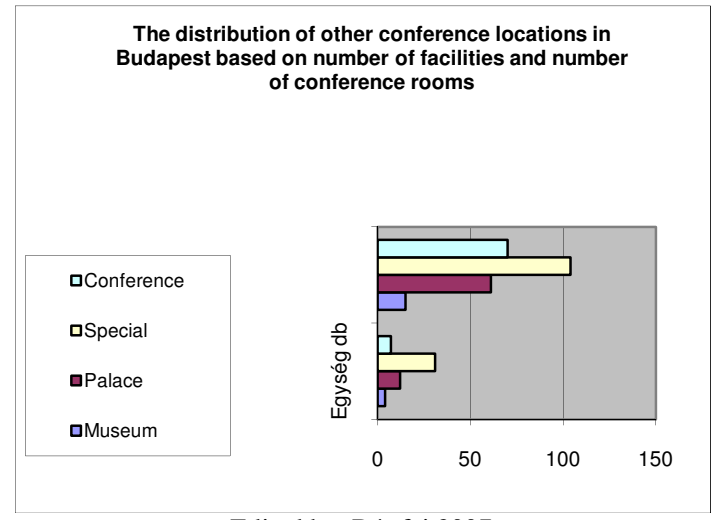

Edited by: Bártfai 2007

Sources: www.itthon.hu, www.hcb.hu

Concerning other conference locations, we can conclude that special locations make the most significant contribution to the total capacity with their share being more than 40\%. One of them is Papp László Budapest Sportaréna, having the largest accommodation potential - it was built to accommodate 12,500 people alone. Among the conference centers, in Hungexpo 3000, the Budapest World Trade Center, 1,755 people can be accommodated at the same time, in a theatre row-like arrangement.

\subsection{MICE Statistics For 2006}

In 2006, 431 conferences (according to the criteria), 29 fairs and exhibitions were organized in Hungary. The average number of nations participating at the conferences was 11.1 , and the duration of the conferences was 4.5 days on average. $75 \%$ of the conferences were organized in Budapest, which means a $2 \%$ increase compared to $2005.31 \%$ of the conference participants were Hungarian and $69 \%$ came from abroad. 
Tourism and Hospitality Management, Vol. 17, No. 1, pp. 131-139, 2011

E. G. Bártfai: BUDAPEST, BRATISLAVA AND VIENNA CONFERENCE FACILITIES ...

The largest segment of conferences was those where the number of participants was between 101-250 persons. Based on location, the percentage distribution of the conferences was the following: conference hotels $76.8 \%$, congress centers $14.4 \%$, other locations $4.2 \%$, universities and scientific institutes $4.6 \%$. The distribution based on major topics: medical science $23.1 \%$, management $26 \%$, sciences $17.6 \%$, transportation $3.9 \%$, information technology $10.6 \%$, tourism $1.9 \%$ (this continuously decreased from its $8 \%$ share in 2003 ), other $22.4 \%$. The average number of participants at conferences in the year 2006, was 238; high season being from the beginning of September until mid-December and from mid-February until mid-July.

\subsection{Comparing The Conference Capacities of Vienna, Bratislava and Budapest}

The three Danube capitals are located fairly close to each other and it is possible to travel from one to the other within 2 hours by car.

Table 2: The conference capacities of Vienna, Bratislava and Budapest (summary table)

\begin{tabular}{|c|c|c|c|c|c|c|}
\hline & & Number & $\begin{array}{l}\text { Conference } \\
\text { Rooms }\end{array}$ & Average & $\begin{array}{l}\text { Minimum } \\
\text { Capacity }\end{array}$ & $\begin{array}{l}\text { Maximum } \\
\text { Capacity }\end{array}$ \\
\hline \multirow{10}{*}{$\begin{array}{l}\mathbf{V} \\
\mathbf{I} \\
\mathbf{E} \\
\mathbf{N} \\
\mathbf{N} \\
\mathbf{A}\end{array}$} & $5 *$ & 13 & 134 & 10.3 & 4,491 & 10,441 \\
\hline & $4 *$ & 42 & 235 & 5.6 & 6,080 & 14,871 \\
\hline & $3 *$ & 5 & 18 & 3.6 & 746 & 1,434 \\
\hline & I. $\Sigma$ & 60 & 387 & 6.45 & 11,317 & 26,746 \\
\hline & Museums & 17 & 63 & 3.7 & 7,766 & 12,400 \\
\hline & Palaces & 11 & 75 & 6.8 & 4,420 & 11,396 \\
\hline & Special & 15 & 94 & 6.3 & 21,415 & 38,474 \\
\hline & Conference & 4 & 81 & 20.2 & 9,554 & 20,243 \\
\hline & II. $\Sigma$ & 47 & 313 & 6.6 & 43,155 & 82,513 \\
\hline & $\Sigma$ I. - II. & 107 & 700 & 6.5 & 54,472 & 109,258 \\
\hline \multirow{10}{*}{$\begin{array}{l}\text { B } \\
\mathbf{R} \\
\mathbf{A} \\
\mathbf{T} \\
\mathbf{I} \\
\mathbf{S} \\
\mathbf{L} \\
\mathbf{A} \\
\mathbf{V} \\
\mathbf{A}\end{array}$} & $5 *$ & - & - & - & - & - \\
\hline & $4 *$ & 49 & 53 & 5.9 & 1,494 & 4,523 \\
\hline & $3 *$ & 14 & 38 & 2.7 & 1,853 & 3,482 \\
\hline & I. $\Sigma$ & 23 & 91 & 3.9 & 3,347 & 8,005 \\
\hline & Museums & 1 & 5 & 5.0 & 725 & 1,235 \\
\hline & Palaces & 1 & 5 & 5.0 & 165 & 490 \\
\hline & Special & 6 & 15 & 2.5 & 2,495 & 3,719 \\
\hline & Conference & 3 & 11 & 3.6 & 3.462 & 9,298 \\
\hline & II. $\Sigma$ & 11 & 36 & 3.2 & 6,847 & 14,742 \\
\hline & $\Sigma$ I. - II. & 34 & 127 & 3.7 & 10,194 & 22,747 \\
\hline \multirow{10}{*}{$\begin{array}{l}\mathbf{B} \\
\mathbf{U} \\
\mathbf{D} \\
\mathbf{A} \\
\mathbf{P} \\
\mathbf{E} \\
\mathbf{S} \\
\mathbf{T}\end{array}$} & $5 *$ & 13 & 96 & 7.4 & 4,614 & 12,534 \\
\hline & $4 *$ & 34 & 170 & 5.0 & 5,570 & 13,008 \\
\hline & $3 *$ & 45 & 130 & 2.9 & 6,271 & 10,400 \\
\hline & I. $\Sigma$ & 92 & 396 & 4.3 & 16,455 & 35,942 \\
\hline & Museums & 4 & 15 & 3.7 & 2,840 & 4,120 \\
\hline & Palaces & 12 & 61 & 5.0 & 5,357 & 8,180 \\
\hline & Special & 31 & 104 & 3.3 & 28,996 & 44,651 \\
\hline & Conference & 7 & 70 & 10.0 & 9,163 & 21,449 \\
\hline & II. $\Sigma$ & 54 & 250 & 4.6 & 46,356 & 78,400 \\
\hline & $\Sigma$ I. - II. & 146 & 646 & 4.4 & 62,811 & 114,342 \\
\hline
\end{tabular}

Edited by: Bártfai 2007

Sources: www.itthon.hu, www.hcb.hu, www.vienna.convention.at/venuefinder, www.sacka.sk/katalog 
Tourism and Hospitality Management, Vol. 17, No. 1, pp. 131-139, 2011

E. G. Bártfai: BUDAPEST, BRATISLAVA AND VIENNA CONFERENCE FACILITIES ...

Vienna leads the 2006 ICCA list, as it is the city where most conferences were held. Budapest is $6^{\text {th }}$ on this list; the rank of Bratislava could not be inferred from any source!

The conference capacities of Bratislava, excluding one location (a conference center of 3,400 places where chairs are allocated in a theatre-like manner - this is the largest in the category- Budapest and Vienna can both offer "only" 3,000), are the smallest in number in all areas, while Vienna and Budapest have almost similar capacities.

Vienna and Budapest both have locations that can accommodate more than 10,000 people and in the five-star category, it is possible to find conference halls that can accommodate over 800. In the hotel category, there is a conspicuous difference between Vienna and Budapest in the three-star hotel capacity, as Vienna has only 5, whereas in Budapest there are 45.

\section{CONCLUSIONS, RECOMMENDATIONS}

In the case of Budapest, one shortcoming can be ascertained: the lack of conference centers that can accommodate more than 5,000 people, which would enable "mega" events to enter the market. Two such buildings are planned to be built by 2010 , one in Lágymányos, called "Spike," and one that is to be built on the territory of Hungexpo. For both buildings, appropriate accommodation facilities have to be established in their vicinity because there are not enough hotel rooms in these two parts of the Hungarian capital. By contrast, on Blaha Lujza Square in the center of the city, there is a location - the former Népszabadság headquarters - that has more than 2,500 hotel rooms in two-, three-, four- and five-star hotels within 1 kilometer.

Based on what I have experienced during the data gathering, I believe it would be expedient to create an up-to-date database, on the basis of which data from the whole country and from Budapest could be registered; a good example of this is the Austrian Conference Office brochure which registers the conference tourism data of the Austrian capital individually based on a very good syllabus.

In the case of "mega" events, I believe that even cooperation between the three cities is possible, involving pre- and post-event programs.

It is important to carry on improving and restoring the positive image of Budapest because this became slightly negative due to the events in autumn of 2006. It is also important concerning this subject, that we have to show visiting foreigners that we like them and we have to spend more money both on development and on marketing propagating the city. 
Tourism and Hospitality Management, Vol. 17, No. 1, pp. 131-139, 2011

E. G. Bártfai: BUDAPEST, BRATISLAVA AND VIENNA CONFERENCE FACILITIES ...

\section{REFERENCES}

Cooper, C., Fletcher, J., Fyall, A., Gilbert, D. and Wanhill, S. (2005), Tourism: Principles and Practice, 3rd edition, Pearson.

Getz, D. (2008), Event Tourism: Definition, Evolution and Research, Tourism Management, Vol. 29, No. 3, pp. 403-428.

Goeldner, C. R., Ritchie J. R. B. (2009), Tourism Principles, Practices, Philosophies, Eleventh Edition, John Wiley \& Sons, Inc. Hoboken, New Jersey.

Faragó, H. (2003), Idegenforgalmi rendezvények és kongresszusok szervezése, Organizing Tourist Events and Congresses, Képzőmüvészeti Kiadó, Budapest.

Holloway, J. C., Humphreys, C. and Davidson, R. (2009), The Business of Tourism, Eight edition, Pearson Education Limited, England.

http://bratislavahotels.travelslovakia.sk/accomodation-in-hotel

http://itthon.hu/servlet/page?_pageid=7378\&

http://www.hcb.hu/images/statistic2006_hu, The 2006 Summary of The MICE Survey of The Hungarian Tourist Office Corp.

http://www.hcb.hu/objects/details.php

http://www.hcb.hu/studies.phtml?lang=hu, Requirements for a conference hotel. A statement by IAPCO.

http://www.hcb.hu/studies.phtml?lang=hu, Planning a conference center. The requirements of PCO-s.

http://www.hcb.hu/studies.phtml?lang=hu, Faragó, H., Karikás, E. (2004), A konferenciák világa, The World of Conferences.

http://www.itthon.hu/images/mtrt/tartalom/bulletin/bulletin_2006_3/mice_piac.html, Simonyi, N. (2007), A magyarországi MICE piac jellemzői 2006 első félévében, The characteristics of the Hungarian MICE market in the first half of 2006.

http://www.itthon.hu/images/mtrt/tartalom/bulletin/bulletin_2006_2/Magyar_turizmus_alakulás_2006.html, Tourism in Hungary in the first half of 2006, The Market and Product Analysis Office of the Hungarian Tourist Office Corp.

http://www.sacka.sk/katalog/exhibition.htm

http://www.sacka.sk/katalog/hotels.htm

http://www.sacka.sk/katalog/unusual.htm

http://www.vienna.convention.at/venuefinder/venue

Meszter, L. ed. (2004), Budapest főváros turisztikai stratégiája és 2010-ig szóló fejlesztési programja, The Tourism Strategy of Budapest and its development plan up to 2010

Simonyi, N. (2006), A konferenciaturizmus nemzetközi piacának áttekintése, An Overview of the International Market of Conference Tourism, Turizmus Bulletin, Volume X., No. 4.

Wiener Tagungsstatistik 2006. Vienna Convention Bureau, Wien.

Whitfield, J. E. (2009), Why and How UK Visitor Attractions Diversify their Product to Offer, Conference and Event Facilities in Journal of Convention \& Event Tourism, 10:72-88.

www.hcb.hu, Thematic background material, MICE - professional tourism.

www.iccaworld.com/aeps/aeitem.cfm?aeid=29, Definition of „MICE”-FAQs ICCA Data Statistics on ICCA. www.iccaworld.com/npps/story.cfm?ID=1305, ICCA publishes country and city rankings 2006.

Endre György Bártfai, PhD, Assistant Professor

Budapest Business School

Faculty of Commerce, Catering and Tourism

Department of Tourism

Alkotmány utca 9-11, 1054 Budapest, Hungary

e-mail: bartfai.endre@kvifk.bgf.hu 